\title{
PENGARUH STATUS GIZI DAN TONSILITIS KRONIK TERHADAP PRESTASI BELAJAR PADA SISWA SEKOLAH DASAR
}

\author{
N Juni Triastuti, Fachroni Rahman, Muhammad Aji Akbar, Muhammad Shoim Dasuki, Retno Sintowati \\ Fakultas Kedokteran Universitas Muhammadiyah Surakarta \\ Email: juni_triastuti@ums.ac.id
}

\begin{abstract}
ABSTRAK
Prestasi belajar merupakan kegiatan yang dilakukan secara sadar dan kontinyu pada seseorang hingga akan megalami perubahan tingkah laku secara keseluruhan artinya perubahan yang senantiasa bertambah baik, apabila prestasi belajar seseorang menurun kemungkinan disebabkan oleh banyak faktor, salah satunya adalah tonsilitis kronis. Penelitian ini bertujuan untuk mengetahui pengaruh status gizi dan tonsilitis kronis dapat berpengaruh terhadap prestasi belajar siswa. Penelitian ini merupakan studi kasus kontrol. Penelitian ini dilaksanakan pada bulan Januari 2015 di SD Negeri 1 Karangasem Surakarta dengan sampel anak kelas 4 sampai kelas 6 sebanyak 55 anak. Teknik sampling menggunakan purposive sampling. Data yang diperoleh dianalisis dengan uji Chi-Square dan uji regresi linear ganda. Sejumlah 55 siswa sekolah dasar mengikuti penelitian ini dimana diantaranya terdapat 26 siswa yang menderita tonsillitis kronis dan 29 siswa tanpa tonsillitis kronis. Selain itu didapatkan data bahwa 30 siswa memiliki status gizi yang baik dan 25 diantaranya memiliki status gizi yang buruk. Berdasarkan hasil analisis uji Chi-Square didapatkan bahwa nilai p value =0,001 untuk pengaruh antara status gizi terhadap prestasi belajar siswa, sementara itu didapatkan pengaruh antara tonsilitis kronis terhadap prestasi belajar dengan nilai p value sebesar 0,000. Sedangkan nilai Chi Square untuk pengaruh antara status gizi terhadap tonsillitis didapatkan nilai p valuenya sebesar 0,000. Berdasarkan uji regresi linear ganda didapatkan nilai p<0,05 yang berarti bahwa status gizi dan tonsillitis secara bersama-sama dapat mempengaruhi prestasi belajar siswa. Terdapat pengaruh antara status gizi dan tonsilitis kronis dengan prestasi belajar pada siswa sekolah dasar.
\end{abstract}

Kata kunci: Status gizi, Tonsilitis Kronis, Prestasi Belajar

\begin{abstract}
Academic achievement is an activity that is done consciously and continuously on a person to be experiencing a change in behavior as a whole means that change are always getting better, if the academic achievement lower down may be caused by many factors, such as nutrient grade and chronic tonsillitis will involved. The aim of this research is determine whether nutrient grade and chronic tonsillitis can influence the academic achievement. This study used cross sectional study. This study was conducted in SD Negeri 1 Karangasem Surakarta with the sample of children in grade 4 to grade 6 as many as 55 children. The measurement including nutrient grade and tonsillitis condition were collected and then be analyzed using Chi-Square. There were 55 students involved, consisting of 26 students with chronic tonsillitis and 29 students without chronic tonsillitis. Another result was found that 30 student were in better nutrient grade and 25 were in lower nutrient grade. From the Chi-Square result showed that the value of $p=0,001$ for the influence of nutrient grade to academic achievement, while $p$ value of influence between chronic tonsillitis and academic achievement in elementary school student was 0,000. The Chi Square result of the influence between nutrient grade to chronic tonsillitis was 0,000. According to linear regression test, it was found that nutrient grade and chronic tonsillitis altogether will influence the academic achievement with $p$ value was 0,000 where $p<0,05$. Nutrient grade and chronic tonsillitis influence academic achievement in elementary school student.
\end{abstract}

Keywords : Nutrient grade, Chronic tonsillitis, Academic achievment 


\section{Pendahuluan}

Kejadian infeksi saluran pernafasan akut (ISPA) di Indonesia masih merupakan penyebab tersering morbiditas dan mortalitas pada anak. Berdasarkan data epidemiologi penyakit THT di tujuh Provinsi di Indonesia, prevalensi tonsilitis kronis 3,8\% tertinggi setelah nasofaringitis akut $4,6 \%$. Penyakit yang terjadi pada tonsil palatina (tonsil) merupakan permasalahan yang umum ditemukan pada anak. Penderita tonsilitis merupakan pasien yang sering datang pada praktek dokter ahli bagian telinga hidung tenggorok bedah kepala dan leher (THT-KL), dokter anak, maupun tempat pelayanan kesehatan lainnya. Tonsilitis (radang pada tonsil) juga merupakan salah satu penyebab ketidakhadiran anak di sekolah (Farokah, 2007).

Prevalensi tonsillitis meningkat sesuai dengan bertambahnya umur, mencapai puncaknya pada umur 4-7 tahun, dan berlanjut hingga dewasa. Insiden tonsilitis streptokokus tertinggi pada usia 5-18 tahun, jarang pada usia di bawah 3 tahun dan sebanding antara laki-laki dan perempuan. Insiden tonsilitis kronis di RS Dr. Kariadi Semarang $23,36 \%$ dan $47 \%$ diantaranya pada usia 6-15 tahun (Farokah, 2007). Mengingat angka kejadian yang tinggi dan dampak yang ditimbulkan dapat mempengaruhi kualitas hidup anak, maka pengetahuan yang memadai mengenai tonsilitis kronik diperlukan guna penegakan diagnosis dan terapi yang tepat dan rasional (Jackson, 2008).

Secara umum, penatalaksanaan tonsilitis kronik dibagi dua yaitu konservatif dan operatif. Terapi konservatif dilakukan untuk mengeliminasi kausa yaitu infeksi, dan mengatasi keluhan yang mengganggu. Bila tonsil membesar dan menyebabkan sumbatan jalan nafas, disfagia berat, gangguan tidur, terbentuk abses, atau tidak berhasil dengan pengobatan konvensional, maka operasi tonsilektomi perlu dilakukan (Hermani, B., dkk, 2007). Selain itu indikasi tonsilektomi pada tonsilitis kronik bila sebagai fokal infeksi, penurunan kualitas hidup dan menimbulkan rasa tidak nyaman (Jackson, 2008).

Salah satu bentuk penurunan kualitas hidup adalah penurunan prestasi belajar. Definisi belajar menurut Suryabrata adalah aktivitas (usaha dengan sengaja) yang dapat menghasilkan perubahan berupa kemampuan baru pada diri individu. Proses dan hasil belajar dipengaruhi oleh berbagai faktor antara lain kondisi fisiologis dan psikologis diri individu. Perubahan perilaku akibat belajar tersebut menandai keberhasilan proses belajar dan mengajar dan digunakan sebagai indikator prestasi belajar (Suryabrata, 2007).

Berdasarkan uraian tersebut diatas dapat dimengerti bahwa anak dengan tonsilitis kronik dapat terganggu kondisi fisiologis dan psikologisnya sehingga dapat mengganggu proses belajar. Permasalahan yang timbul disini adalah apakah benar pada anak dengan tonsilitis kronik memiliki prestasi belajar yang kurang.

Penelitian yang sudah ada tentang tonsilitis kronik dilakukan oleh Khargoshaie dkk, kepada siswa kelas 4 SD yang menunjukan bahwa tidak ada hubungan yang signifikan antara prestasi belajar dengan ukuran tonsil pada penderita tonsilitis kronik hipertrofi. Penelitian lain oleh Farokah, terhadap siswi Sekolah Dasar kelas 2 di kota Semarang memiliki hasil berbeda dengan penelitian Khargoshaie dkk yang mana hasil penelitianya mengemukakan bahwa terdapat hubungan yang signifikan antara tonsilitis kronik dengan prestasi belajar siswa (Kargoshaie A. et al., (2009).

Penyakit pada tonsil palatina (tonsil) merupakan permasalahan yang umum ditemukan pada anak. Untuk itu program perbaikan gizi bertujuan untuk meningkatkan mutu gizi konsumsi pangan, agar terjadi perbaikan status gizi masyarakat (Muchtadi, D. 2009).

Status gizi adalah ukuran keberhasilan dalam pemenuhan nutrisi untuk anak yang diindikasikan oleh berat badan dan tinggi badan anak. Status gizi juga didefinisikan sebagai status kesehatan yang dihasilkan oleh keseimbangan antara kebutuhan dan masukan nutrien. Penelitian status gizi merupakan pengukuran yang didasarkan pada data antropometri serta biokimia dan riwayat diit (Suhardjo, 2005).

Anak sekolah atau masa kanak-kanak pertengahan merupakan salah satu kelompok yang rentan terhadap ketidakcukupan gizi, sehingga anak sekolah harus dipantau agar ketidakcukupan gizi bisa dihindari. Anak sekolah adalah anak yang berusia 6-12 tahun, memiliki fisik lebih kuat dibandingkan balita atau anak usia prasekolah, mempunyai sifat individual serta aktif dan tidak bergantung dengan orang tua. Kelompok anak sekolah pada umumnya mempunyai kondisi gizi yang lebih baik daripada kelompok balita. Meskipun demikian, masih 
terdapat berbagai kondisi gizi anak sekolah yang tidak memuaskan, misalnya: berat badan yang kurang, anemia defisiensi Fe, defisiensi vitamin $\mathrm{C}$, dan di daerah-daerah tertentu juga dijumpai defisiensi Iodium (Petrus, 2003).

Anak usia remaja perlu dipantau keadaan gizinya, karena anak tersebut sedang masa pertumbuhan. Secara fisik keadaan gizi anak harus baik dan seimbang, karena gizi adalah salah satu faktor yang mempengaruhi kesegaran jasmani. Semua aktifitas dapat dilakuakan dengan baik jika anak mengkonsumsi makanan yang bergizi secara baik dan seimbang. Untuk mengetahui gizi baik dan seimbang perlu diketahui kegunan zat-zat gizi sebagai berikut : 1) Membangun dan memelihara tubuh, terutama pada ada terjadi pembentukan selsel baru guna membangu bagian-bagian tubuh misalnya otot, tulang, darah, otak dan organ-organ lainya. 2) Memberi tenaga pada tubuh, bahan makanan penghasil energi ialah bahan makanan pokok. Zat gizi utama yang menghasilkan energi adalah karbohidrat khususnya zat tepung (amylum). Bahan makanan penghasil energi berasal dari karbohidrat dan protein. Energi dalam jumlah besar terutama di perlukan untuk kerja otot skelet yang melakukan kerja luar para pekerja kasar memerlukan makanan pokok dalam jumlah besar untuk sanggup melakukan pekerjanpekerjaan berat. 3) Mengatur proses faal tubuh, zat-zat gizi yang diperlukan untuk mengatur proses faal tersebutdisebut zat pelindung, yaitu protein, mineral, vitamin dan air. Bahan pengatur zat gizi pengatur ialah sayur dan buah. Zat gizi pengatur dapat menjalankan dan mengatur proses metabolisme tubuh (Suhardjo, 2005).

Masalah gizi anak secara garis besar merupakan dampak dari ketidakseimbangan antara asupan dan keluaran zat gizi (nutritional imbalance), yaitu asupan yang melebihi keluaran atau sebaliknya, di samping kesalahan dalam memilih bahan makanan untuk disantap (Arisman, 2009).

Pengaruh makanan terhadap otak, apabila makanan tidak cukup mengandung zat-zat gizi yang dibutuhkan, dan keadaan ini berlangsung lama, akan menyebabkan perubahan metabolisme dalam otak, berakibat terjadi ketidakmampuan berfungsi normal. Pada keadaa yang lebih berat dan kronis, kekurangan gizi menyebabkan pertumbuhan badan terganggu, badan lebih kecil diikuti dengan ukuran otak yang juga kecil. Jumlah sel dalam otak berkurang dan terjadi ketidakmatangan dan ketidaksempurnaan organisasi biokimia dalam otak. Keadaan ini berpengaruh terhadap perkembangan kecerdasan anak. Selain itu akibat dari kekurangan zat gizi makanan akan mempengaruhi daya tahan anak terhadap penyakit, sehingga anak mudah terkena sakit dan anak menjadi kurang konsentrasi (Anwar, 2008).

Berdasarkan uraian tersebut di atas, diketahui bahwa faktor gizi sangat berpengaruh terhadap perkembangan otak, daya tahan terhadap penyakit serta kurangnya konsentrasi. Masa pertumbuhan anak sangat rentan sehingga diperlukan keseimbangan antara asupan dan kebutuhan zat gizi. Zat gizi mempengaruhi pertumbuhan, kecerdasan, kesehatan, dan hal-hal lain di dalam perkembangan otak anak.

Dari uraian di atas, penulis tertarik melakukan penelitian untuk mengetahui apakah ada pengaruh status gizi dan tonsilitis kronis pada anak terhadap prestasi belajar anak di sekolah dasar.

Tujuan penelitian ini adalah untuk mengetahui apakah terdapat pengaruh status gizi dan tonilitis kronik terhadap prestasi belajar pada siswa sekolah dasar.

\section{Metodologi Penelitian}

Jenis penelitian ini adalah penelitian observasi analitik yaitu rancangan penelitian yang bertujuan mencari hubungan antar variabel yang sifatnya bukan sebab akibat, biasanya dilakukan penelitian secara deskriptif terlebih dahulu untuk dicari data dasar (Hidayat, A.A., (2007). Rancangan penelitian yang digunakan adalah penelitian cross sectional study. Penelitian ini dilakukan di SD Karangasem I dan melibatkan siswa dari kelas 4-6 berjumlah 55 siswa. Teknik sampling yang digunakan adalah purposive sampling. Data penelitian ini terdiri dari data primer berupa data status gizi dan tonsillitis siswa dan data sekunder berupa prestasi belajar siswa berupa rapor siswa. Data penelitian yang sudah terkumpul kemudian di analisis dengan uji Chi Square dan analisis regresi ganda. 


\section{Hasil Penelitian dan Pembahasan}

Penelitian ini dilaksanakan di Sekolah Dasar Negeri 1 Karangasem kecamatan Laweyan kota Surakarta, dengan cara pengukuran status gizi menggunakan tinggi badan, berat badan, dan umur pada siswa dan siswi kelas 4, 5, dan 6. Penelitian ini dilakukan pada tanggal 12 Januari 2015 dengan total sampel 55 anak yang terdiri atas: kelas 4 berjumlah 18 anak, kelas 5 berjumlah 22 anak, dan kelas 6 berjumlah 15 anak. Adapun hasil dari penelitian yang telah dilakukan didapatkan hasil sebagai berikut: hubungan status gizi terhadap prestasi belajar anak sekolah dasar dapat diketahui dengan analisis data menggunakan aplikasi IBM SPSS Statistics Version 22 dengan uji chi-square, hasil dari uji chi-square yang telah dilakukan dapat dilihat pada tabel 1 dibawah ini:

Tabel 1. Hasil Uji Chi-Square Pengaruh Status Gizi Terhadap Prestasi Belajar.

\begin{tabular}{cccccc}
\hline & Value & Df & $\begin{array}{c}\text { Asymp. } \\
\text { Sig. } \\
(2-\text {-sided })\end{array}$ & $\begin{array}{c}\text { Exact } \\
\text { Sig. } \\
(2-\text {-sided })\end{array}$ & $\begin{array}{c}\text { Exact Sig. } \\
\text { (1-sided) }\end{array}$ \\
\hline $\begin{array}{c}\text { Pearson Chi- } \\
\text { Square }\end{array}$ & $11,065^{\mathrm{b}}$ & 1 &, 001 & & \\
\hline
\end{tabular}

Sumber: IBM SPSS Statistics Version 2.

Berdasarkan dari data statistic didapatkan nilai expected count tiap sel kurang dari 5, sehingga memenuhi syarat untuk dilakukan uji analisis menggunakan uji chi-square. Hasil uji analisis dengan taraf signifikan $(\alpha)$ 0,05 diperoleh $\mathrm{p}$ value sebesar 0,001 di mana batas dikatakan bermakna jika $\mathrm{p}$ value $<0,05$. Nilai $\mathrm{p}$ value sebesar 0,001 bermakna signifikan, sehingga terdapat pengaruh status gizi terhadap prestasi belajar anak sekolah dasar yang signifikan.

Tabel 2. Hasil Uji Chi-Square Pengaruh Tonsilitis Terhadap Prestasi Belajar.

\begin{tabular}{lccccc}
\hline & Value & Df & $\begin{array}{c}\text { Asymp. Sig. } \\
\text { (2-sided })\end{array}$ & $\begin{array}{c}\text { Exact Sig. } \\
(2 \text {-sided })\end{array}$ & $\begin{array}{c}\text { Exact Sig. } \\
\text { (1-sided })\end{array}$ \\
\hline $\begin{array}{c}\text { Pearson Chi- } \\
\text { Square }\end{array}$ & $28,722^{\mathrm{b}}$ & 1 &, 000 & & \\
\hline
\end{tabular}

Sumber: IBM SPSS Statistics Version 2.

Berdasarkan dari data statistic didapatkan nilai expected count tiap sel kurang dari 5, sehingga memenuhi syarat untuk dilakukan uji analisis menggunakan uji chi-square. Hasil uji analisis dengan taraf signifikan $(\alpha)$ 0,05 diperoleh $\mathrm{p}$ value sebesar 0,000 di mana batas dikatakan bermakna jika $\mathrm{p}$ value $<0,05$. Nilai $\mathrm{p}$ value sebesar 0,001 bermakna signifikan, sehingga terdapat pengaruh tonsillitis kronis terhadap prestasi belajar anak sekolah dasar secara signifikan.

Tabel 3. Hasil Uji Chi-Square Pengaruh Status Gizi Terhadap Tonsilitis kronis.

\begin{tabular}{lccccc}
\hline & Value & Df & $\begin{array}{c}\text { Asymp. Sig. } \\
(2-s i d e d)\end{array}$ & $\begin{array}{c}\text { Exact Sig. } \\
(2 \text {-sided })\end{array}$ & $\begin{array}{c}\text { Exact Sig. } \\
(1 \text {-sided })\end{array}$ \\
\hline $\begin{array}{c}\text { Pearson Chi- } \\
\text { Square }\end{array}$ & $30,500^{\mathrm{b}}$ & 1 &, 000 & & \\
\hline
\end{tabular}

Sumber: IBM SPSS Statistics Version 2. 
Berdasarkan dari data statistik didapatkan nilai expected count tiap sel kurang dari 5, sehingga memenuhi syarat untuk dilakukan uji analisis menggunakan uji chi-square. Hasil uji analisis dengan taraf signifikan $(\alpha)$ 0,05 diperoleh $\mathrm{p}$ value sebesar 0,000 di mana batas dikatakan bermakna jika $\mathrm{p}$ value $<0,05$. Nilai $\mathrm{p}$ value sebesar 0,000 bermakna signifikan, sehingga terdapat pengaruh status gizi terhadap tonsillitis kronis pada anak sekolah dasar secara signifikan.

Tabel 4. Hasil Uji Regresi linear ganda Pengaruh Status Gizi dan Tonsilitis Terhadap Prestasi Belajar.

\begin{tabular}{|c|c|c|c|c|c|}
\hline & $\mathrm{F}$ & Df & $\begin{array}{l}\text { Asymp. Sig. } \\
\text { (2-sided) }\end{array}$ & $\begin{array}{l}\text { Exact Sig. } \\
\text { (2-sided) }\end{array}$ & $\begin{array}{c}\text { Exact Sig. } \\
\text { (1-sided) }\end{array}$ \\
\hline Regression & 30,551 & 2 &, $000^{\mathrm{a}}$ & & \\
\hline
\end{tabular}

Hasil uji analisis dengan taraf signifikan (a) 0,05 diperoleh p value sebesar 0,000 di mana batas dikatakan bermakna jika $\mathrm{p}$ value $<0,05$. Nilai p value sebesar 0,000 bermakna signifikan, sehingga faktor status gizi dan tonsillitis kronis secara bersama-sama dapat mempengaruhi prestasi belajar anak sekolah dasar.

Hasil penelitian yang telah dianalisis dengan uji chi-square menunjukan hubungan yang signifikan status gizi terhadap prestasi belajar. Hubungan tersebut dapat dikatakan signifikan karena diperoleh nilai $\mathrm{p}$ value sebesar 0,001 di mana batas dikatakan bermakna jika $\mathrm{p}$ value $<0,05$.

Status gizi menjadi indikator ketiga dalam menentukan derajat kesehatan anak. Status gizi yang baik dapat membantu proses pertumbuhan dan perkembangan anak untuk mencapai kematangan yang optimal. Pemantauan status gizi juga dapat digunakan sebagai bentuk antisipasi dalam merencanakan perbaikan status kesehatan anak (Hidayat, 2009).

Salah satu cara penilaian yang status gizi biasa dipergunakan ialah cara pengukuran antropometri. Pengukuran antropometri merupakan penilaian status gizi yang lebih praktis, cukup teliti, mudah dilakukan. Penelitian ini dapat dilakukan oleh siapa saja dengan latihan yang sederhana (Suhardjo, 2005).

Status gizi anak umur 6-18 tahun dikelompokan menjadi tiga kelompok umur yaitu 6-12 tahun, 13-15 tahun dan 16-18 tahun. Indikator status gizi yang digunakan untuk kelompok umur ini didasarkan pada pengukuran antropometri berat badan (BB) dan tinggi badan (TB) yang disajikan dalam bentuk tinggi badan menurut umur (TB/U) dan Indeks Massa Tubuh menurut umur (IMT/U) (Balitbang Kemenkes RI, 2010).
Status gizi yang baik masa lampau khususnya masa pertumbuhan, akan menghasikan pertumbuhan otak yang normal sehingga akan berpengaruh baik pada intelektual anak. Sebaliknya status gizi yang tidak baik akan menghasilkan pertumbuhan otak yang tidak normal dimana tidak dapat direcovery (Petrus, 2003). Kandungan gizi dalam makanan sangat mempengaruhi pertumbuhan sel otak. Pertumbuhan sel otak yang sempurna penting untuk diperhatikan. Pertumbuhan otak yang sempurna dapat menjadi dasar kecerdasan seseorang (Soenardi, 2007).

Pendidikan merupakan salah satu faktor yang sangat fundamental dalam upaya meningkatkan kualitas kehidupan, serta faktor penentu bagi perkembangan sosial dan ekonomi kearah kondisi yang lebih baik. Pendidikan juga dipandang sebagai sarana paling strategis untuk mengangkat harkat dan martabat suatu bangsa. Pentingnya peran pendidikan bagi kehidupan masyarakat maka pemerintah dewasa ini sangat memperhatikan segala aspek pendidikan yang ada untuk ditingkatkan (Sukardi, 2008).

Penelitian ini meggunakan sampel sebanyak 55 anak Sekolah Dasar usia 9-12 tahun di SDN 1 Karangasem Surakarta. Penelitian ini dilakukan dengan cara pengukuran status gizi menggunakan tinggi badan, berat badan, dan umur pada siswa dan siswi kelas 4,5 , dan 6 . Jenis penelitian yang digunakan pada penelitian ini adalah observasional analitik dengan pendekatan cross sectional. Pada anak sekolah, anak usia 6-12 tahun banyak berhubungan dengan orang-orang diluar keluarganya dan berkenalan dengan suasana serta lingkungan baru dalam kehidupannya. Pada usia ini, anak mempunyai banyak aktivitas diluar rumah sehingga terkadang melupakan 
waktu makan. Selain itu, anak juga sudah aktif memilih makanan yang disukai sehingga dapat mempengaruhi kebiasaan makan mereka dan akhirya dapat mempengaruhi status gizinya (Moehji, S., 2007).

Hasil dari penelitian 43 sampel anak sekolah yang diteliti di kabupaten Nabire, Papua terdapat $36 \%$ anak menderita gizi kurang dan $1,3 \%$ mengalami gizi buruk. Penelitian ini menyatakan terdapat hubungan yang erat antara status gizi dengan prestasi belajar siswa sekolah dasar yaitu semakin tinggi status gizi siswa maka akan semakin tinggi pula prestasi belajar mereka (Huwae, 2005).

Penelitian Tricahyono (2009), menyatakan dari 479 sampel yang diteliti di kecamatan Tingkir kabupaten Salatiga terdapat 12,5\% anak menderita gizi tidak baik dan terdapat 9,6\% anak mempunyai nilai rendah. Penelitian ini menyatakan terdapat hubungan antara status gizi dengan prestasi belajar siswa sekolah dasar yaitu semakin tinggi status gizi siswa maka akan semakin tinggi pula prestasi belajar mereka.

Hasil penelitian dari 70 sampel yang diteliti di kecamatan Tuntang kabupaten Semarang terdapat $54,3 \%$ anak menderita gizi tidak normal dan terdapat 52,9\% anak mempunyai nilai kurang. Penelitian ini menyatakan terdapat hubungan antara status gizi dengan prestasi belajar siswa sekolah dasar yaitu semakin tinggi status gizi siswa maka akan semakin tinggi pula prestasi belajar mereka (Ristiyanti, 2014).

Berdasarkan data hasil penelitian dapat diketahui anak dengan status gizi baik dan prestasi belajar baik sebanyak 25 anak atau 45,5\% dari jumlah sampel sedangkan anak dengan status gizi baik dan prestasi belajar tidak baik terdapat 5 anak atau 9,1\%. Jumlah anak dengan status gizi tidak baik sebanyak 25 anak atau $45,4 \%$ dimana terdapat anak dengan gizi tidak baik dan prestasi belajar baik sebanyak 10 anak serta 15 anak dengan gizi tidak baik dan prestasi belajar tidak baik.

Berdasarkan hasil penelitian ini yang telah dianalisis dengan uji chi-square menunjukan hubungan yang signifikan antara status gizi terhadap tonsillitis kronis. Hubungan tersebut dapat dikatakan signifikan karena diperoleh nilai p value sebesar 0,000 di mana batas dikatakan bermakna jika $\mathrm{p}$ value $<0,05$.

Pengaruh makanan terhadap perkembangan otak, apabila makanan tidak cukup mengandung zat-zat gizi yang dibutuhkan, dan keadaan ini berlangsung lama, akan menyebabkan perubahan metabolisme dalam otak, berakibat terjadi ketidakmampuan berfungsi normal. Pada keadaan yang lebih berat dan kronis, kekurangan gizi menyebabkan pertumbuhan badan terganggu, badan lebih kecil diikuti dengan ukuran otak yang juga kecil. Jumlah sel dalam otak berkurang dan terjadi ketidakmatangan dan ketidaksempurnaan organisasi biokimia dalam otak. Keadaan ini berpengaruh terhadap perkembangan kecerdasan anak (Anwar, 2008). Kekurangan atau kelebihan zat-zat esensi gizi bisa mempengaruhi terjadinya learning disabilities (gangguan belajar), bekerja kurang, kesakitan sampai kematian. Masalahmasalah gizi yang terjadi di Indonesia masih sangat banyak antara lain Kekurangan Energi Protein (KEP), Anemia, KurangVitamin A (KVA), Gangguan Akibat Kekurangan Yodium (GAKY) yang sangat mempengaruhi konsentrasi dan kemampuan belajar siswa (Depkes, 2009).

Tonsilitis banyak disebabkan oleh virus harus ditangani secara simptomatik serta dengan meningkatkan daya tahan tubuh. Sementara itu kekurangan zat gizi makanan akan sangat mempengaruhi daya tahan tubuh utamanya terhadap penyakit seperti tonsillitis yang disebabkan oleh virus (Desai et al., 2008).

Pada penelitian ini didapatkan data bahwa anak yang memiliki status gizi buruk sebanyak $28,2 \%$ hal ini terjadi dikarenakan faktor-faktor yang mempengaruhi prestasi belajar ada banyak faktor diantara ada faktor intelegensia, bakat, motivasi belajar, pola asuh dan pendidikan anak dan lain-lain.

Dari hasil uji Chi Square di dapatkan nilai expected lebih dari 5 maka layak di uji dengan chisquare dengan nilai $\mathrm{p}$ yang di dapat adalah 0,000 karena nilai $\mathrm{P}<0,05$ maka secara statistik terdapat hubungan antara tonsillitis kronis dengan prestasi belajar pada siswa sekolah dasar.

Menurut hasil penelitian didapatkan bahwa penderita tonsilitis kronis mendapatkan prestasi belajar lebih rendah dari pada siswa yang tidak mengalami tonsilitis kronis dimungkinkan siswa dengan tonsilitis kronis sudah menimbulkan gangguan lebih besar seperti gangguan tidur karena sebagian besar dari data kuesioner yang diperoleh menunjukkan bahwa ada keluhan mendengkur dan sering terbangun tengah malam dan gangguan tersebut sangat mengganggu saaat 
proses belajarnya menyebabkan prestasinya lebih rendah dari siswa yang tidak mengalami tonsilitis kronis. Bagaimanapun cerdas dan rajinnya siswa bila mengalami penyakit kronis maka susah sekali untuk memperoleh kemajuan dalam pelajarnya (Kargoshaie A. et al., (2009). Hasil penelitian ini sesuai dengan hasil penelitian yang dilakukan oleh Farokah (2007) mengenai hubungan tonsilitis kronis dengan prestasi belajar. Dia menyatakan terdapat hubungan yang bermakna pada proporsi tonsilitis kronis terhadap penurunan prestasi belajar.

Tonsil dan adenoid hipertrofi yang menyebabkan obtstruksi saluran pernafasan pada waktu tidur dengan hipoventilasi alveoli dan hipoksia pada malam hari dapat mengganggu efek fisiologis dan psikologis. Gejala yang ditimbulkan berupa mengantuk pada siang hari, perhatian berkurang, berat badan berkurang, penurunan fungsi intelektual dan prestasi belajar berkurang (Desai S., Scannapieco F.A., Lepore M., Anolik R., Glick M., (2008).

Prestasi belajar pada siswa dengan tonsiltis kronis yang kurang dari nilai rata-rata dapat merupakan dampak dari penyakit kronis selain itu intelegensi merupakan salah satu faktor penting yang menentukan berhasil atau gagalnya belajar seseorang terutama pada anak-anak. Seorang siswa bila menderita penyakit kronis maka akan sulit memperoleh kemajuan dalam proses belajarnya. Gejala-gejala akibat kondisi fisiologis siswa yang mengalami tonsilitis kronis merupakan penghalang untuk mengikuti pembelajaran. jika gejala semakin mengganggu kondisi fisiologis maka kemungkinan besar mengakibatkan siswa yang mendeerita tonsilitis kronis tidak dapat belajar sama sekali (Hermani B, fachrudin D, Syahrial, et al., (2007).

Hasil analisis diatas juga menyebutkan bahwa beberapa anak yang mengalami tonsillitis kronis masih banyak memiliki nilai yang baik. Hasil ini sesuai dengan pendapat yang disampaikan oleh Suryabrata S., (2007) bahwa prestasi belajar seorang anak dapat dipengaruhi oleh Faktor-faktor yang berasal dari dalam diri individu, digolongkan menjadi faktor fisiologis dan psikologis. Faktor fisiologis meliputi kecukupan nutrisi atau makanan, kondisi kesehatan tubuh, dan fungsi panca indera. Sedangkan faktor psikologis yang mempengaruhi prestasi belajar meliputi perhatian/ konsentrasi, pengamatan, tanggapan, ingatan, perasaan dan motivasi.

Kondisi fisiologis dan psikologis pelajar memegang peranan penting dalam menentukan prestasi belajar. Individu dengan kondisi segar jasmani dan dalam keadaan psikologis yang baik akan berbeda belajarnya dengan individu yang dalam keadaan tidak segar maupun yang tidak baik kondisi jasmani dan psikologisnya (Farokah, 2007).

Salah satu faktor yang merupakan kelemahan pada penelitian ini ialah intelegensi yang tinggi pada anak, karena anak yang mempunyai intelegensi tinggi dan memiliki status gizi rendah bisa memiliki prestasi belajar yang tinggi menyebabkan status gizi yang rendah tidak berpengaruh pada prestasi belajar anak tersebut. Pada penelitian ini masih terdapat keterbatasan dalam mengetahui cara mendidik orang tua terhadap anak di rumah dan asupan gizi yang diberikan orang tua terhadap anak, serta pendidikan diluar sekolah yang diikuti anak.

\section{Simpulan}

Berdasarkan data dari penelitian yang telah dilakukan mengenai pengaruh status gizi dan tonsillitis kronis terhadap prestasi belajar siswa Sekolah Dasar Negeri Karangasem Surakarta, didapatkan kesimpulan bahwa terdapat pengaruh yang bermakna antara status gizi terhadap prestasi belajar anak sekolah dasar dengan nilai $p$ value sebesar 0,001 ; terdapat pengaruh yang bermakna antara tonsillitis kronis terhadap prestasi belajar anak sekolah dasar dengan nilai $p$ value table sebesar 0,000 ; terdapat pengaruh yang bermakna antara status gizi terhadap tonsillitis kronis dengan nilai $p$ value table sebesar 0,000 ; terdapat pengaruh status gizi dan tonsillitis kronis secara bersama-sama terhadap prestasi belajar dengan $p$ value sebesar 0,000 .

\section{Daftar Pustaka}

Arisman, 2007. Prosedur Penelitian (Suatu Pendekatan dan Praktis). Jakarta: Rineka Cipta.

Arisman, 2007. Gizi dalam Daur Kehidupan: Buku Ajar Ilmu Gizi. Jakarta: EGC.

Azwar, S., 2007. Tes Prestasi : Fungsi dan Pengembangan Pengukuran Prestasi Belajar. Cetakan kesepuluh. Yogyakarta: Pustaka Pelajar. 
Balitbang Kemenkes RI, 2010. Badan Penelitian Dan Pengembangan Kesehatan Kementerian Kesehatan Republik Indonesia. Riset Kesehatan Dasar 2010 (Rikesdas).

Depkes RI, 2009. Analisis Situasi Gizi dan Kesehatan Masyarakat. Direktorat Jenderal Bina Kesehatan Masyarakat Direktorat Gizi Masyarakat Jakarta. Dinkes Kabupaten Luwu Utara. 2009. Tentang Gizi Buruk, Faktor-Faktor Terjadinya Gizi Buruk.

Desai S., Scannapieco F.A., Lepore M., Anolik R., Glick M., (2008). Disease of the Respiratory Tract. In: Greenberg M.S., Glick M., Ship J.A., (eds). Burket's Oral Medicine. Hamilton, Ontario. Petrice Custance, 305 - 306.

Farokah, Suprihati, Suyitno S., (2007). Hubungan tonsilis kronik dengan prestasi belajar siswa kelas II sekolah dasar di kota semarang. Cermin Dunia Kedokteran;155:87-92

Hermani B, Fachrudin D, Syahrial, dkk, (2007). Tonsilektomi Pada Anak dan Dewasa. HTA Indonesia, hal. 25-1.

Hidayat, A. 2009. Metode Penelitian Keperawatan dan Teknik Analisis Data. Jakarta: Salemba Medika.

Hidayat, A. 2007. Metode Penenlitian kebidanan dan Teknik Analisis Data. Jakarta: Salemba Medika.

Hidayat, A.A., (2007). Metode Penelitian Kebidanan \& Teknik Analisis Data. Jakarta: Salemba Medika

Huwae, 2005. Hubungan Antara Status Gizi dan Kadar Hb Dengan Prestasi Belajar Murid Sekolah Dasar di Daerah Endemis Malaria. Program Sarjana Universitas Gajah Mada. Tesis.

Jackson, C., (2008). Disease of the Nose, Throat and Ear, $2^{\text {nd }}$ ed.. WB Saunders Co; 239-57.

Kargoshaie A. et al., (2009) The correlation between tonsil size and academic performance is not a direct one, but the result of various factors. Acta Otorhinolaryngologica Italia ;29:258255.

Moehji, S. 2007. Ilmu Gizi Pengetahuan Dasar Ilmu Gizi. Jakarta: Papas Sinar Suanti.

Muchtadi, D. 2009. Pengantar Ilmu Gizi. Bandung: Alfabeta.

Petrus. 2003. Status Gizi, intelegensi dan Prestasi Belajar Murid Sekolah Dasar Suku Bajau di Kecamatan Tinanggea Kabupaten Kendari. Universitas Gajah Mada, Yogyakarta. Tesis.

Ristiyanti, 2014. Hubungan Antara Status Gizi dan Prestasi Belajar Murid SD Negeri di Kecamatan Tuntang Kabupaten Semarang. Program Sarjana Universitas Muhammadiyah Surakarta. Skripsi

Soenardi, T. 2007. Makanan Balita Untuk Tumbuh Sehat dan Cerdas Cetakan ke 12. Jakarta: PT. Gramedia Pustaka Utama.

Sukardi, T. 2008. Peningkatan Profesionalisme Guru Mencermati Kualitas Sumber Daya Guru Sekolah Dasar di Eks. Karesidenan Banyumas. (jurnal.ump.ac.id/index.php/ khasanah/article/download/511/473 diakses pada tanggal 18 Februari 2015).

Suhardjo. 2005. Perencanaan Pangan dan Gizi. Jakarta: Bumi Aksara.

Sunarto. 2009. Pengertian prestasi belajar. Fasilitator idola (online). Tersedia : http://sunartombs. wordpress.com/2009/01/05/pengertianprestasi-belajar/ diakses pada tanggal 25 Januari 2015).

Suryabrata S., (2007) Psikologi Pendidikan. Jakarta; Fajar Interpratama Offiset, hal: 66-54

Tricahyono. 2009. Hubungan Antara Status Gizi dan Prestasi Belajar di SD Kecamatan Tingkir Salatiga. Program Sarjana Universitas Muhammadiyah Surakarta. Skripsi. 